Meta

Journal des traducteurs

Translators' Journal

\title{
Aristophanes in Comic Books: Adaptation as Metabase
}

\section{Dimitris Asimakoulas}

Volume 61, numéro 3, décembre 2016

URI : https://id.erudit.org/iderudit/1039219ar

DOI : https://doi.org/10.7202/1039219ar

Aller au sommaire du numéro

\section{Éditeur(s)}

Les Presses de l’Université de Montréal

ISSN

0026-0452 (imprimé)

1492-1421 (numérique)

Découvrir la revue

Citer cet article

Asimakoulas, D. (2016). Aristophanes in Comic Books: Adaptation as Metabase. Meta, 61(3), 553-577. https://doi.org/10.7202/1039219ar

\section{Résumé de l'article}

Les chercheurs en traduction s'engagent depuis longtemps dans une discussion critique sur la traduction comme mode de réécriture créatrice à partir d'un texte d'origine qui arrive à traverser diverses modalités ainsi que des cultures et des zones temporelles différentes. Les spécialistes dans le domaine de l'adaptation se servent de cette même hypothèse pour étudier la construction et la réception des oeuvres adaptées aux conditions locales. Cet article profite de ces perspectives pour illuminer une partie moins développée de

l'adaptation des comédies, c'est-à-dire l'adaptation des comédies d'Aristophane en bandes dessinées et leur transposition en livre électronique anglais (Metaichmio 2012). L'article suggère un modèle pour une lecture attentive aux transpositions matérielles et créatrices qui s'y effectuent. Ce modèle est basé sur la typologie de Lefèvre $(2011 ; 2012)$ des caractéristiques formelles des bandes dessinées et sur la théorie générale d'Attardo sur l'humour verbal (2002). Il est démontré que le rythme visuel et les relations texte-image créent un environnement fertile pour l'anachronisme, la parodie, l'invention de personnages comiques et les commentaires idéologiques, autant d'aspects qui sont mis au service d'une intrigue condensée. La traduction anglaise réécrit les références culturelles et/ou idéologiques, amplifie l'obscénité et accroît la visibilité du narrateur, en prenant toujours en compte la mise en scène.
Ce document est protégé par la loi sur le droit d'auteur. L'utilisation des services d’Érudit (y compris la reproduction) est assujettie à sa politique d'utilisation que vous pouvez consulter en ligne.

https://apropos.erudit.org/fr/usagers/politique-dutilisation/ 


\title{
Aristophanes in Comic Books: Adaptation as Metabase
}

\author{
DIMITRIS ASIMAKOULAS \\ University of Surrey, Guildford, United Kingdom \\ D.Asimakoulas@surrey.ac.uk
}

\begin{abstract}
RÉSUMÉ
Les chercheurs en traduction s'engagent depuis longtemps dans une discussion critique sur la traduction comme mode de réécriture créatrice à partir d'un texte d'origine qui arrive à traverser diverses modalités ainsi que des cultures et des zones temporelles différentes. Les spécialistes dans le domaine de l'adaptation se servent de cette même hypothèse pour étudier la construction et la réception des œuvres adaptées aux conditions locales. Cet article profite de ces perspectives pour illuminer une partie moins développée de l'adaptation des comédies, c'est-à-dire l'adaptation des comédies d'Aristophane en bandes dessinées et leur transposition en livre électronique anglais (Metaichmio 2012). L'article suggère un modèle pour une lecture attentive aux transpositions matérielles et créatrices qui s'y effectuent. Ce modèle est basé sur la typologie de Lefèvre $(2011$; 2012) des caractéristiques formelles des bandes dessinées et sur la théorie générale d'Attardo sur l'humour verbal (2002). Il est démontré que le rythme visuel et les relations texteimage créent un environnement fertile pour l'anachronisme, la parodie, l'invention de personnages comiques et les commentaires idéologiques, autant d'aspects qui sont mis au service d'une intrigue condensée. La traduction anglaise réécrit les références culturelles et/ou idéologiques, amplifie l'obscénité et accroît la visibilité du narrateur, en prenant toujours en compte la mise en scène.
\end{abstract}

\section{ABSTRACT}

Translation studies researchers have for a long time critically engaged with the idea of translation being a mode of creative rewriting across media and cultural or temporal divides. Adaptation studies experts use a similar premise to study products, processes and reception of adaptations for specific locales. This article combines such perspectives in order to shed light on an under-researched area of comic adaptation: this is the metabase, or transfer, of Aristophanic comedies to the comic book format in Greek and their subsequent translation into English for an e-book edition (Metaichmio Publications 2012). The paper suggests a model for the close reading of creative transfer based on Lefèvre's (2011; 2012) typology of formal properties of comics and Attardo's (2002) General Theory of Verbal Humour. As is shown, visual rhythm and text-image relations create a rich environment for anachronism, parody, comic characterisation and ideological comments, all of which serve a condensed plot. The English translation rewrites cultural/ideological references, amplifies obscenity and emphasizes narrator visibility, always taking into consideration the mise en scène.

\section{MOTS-CLÉS/KEYWORDS}

adaptation, Aristophane, bandes dessinées, grec, humour adaptation, Aristophanes, comics, humour, Greek 


\section{What's so important about Aristophanes?}

Interlingual transfer and transfer across media have become increasingly intertwined in translation studies. Localisation, advertisement translation and especially audiovisual translation are leading the way in what can be seen as a genuine 'inter-semiotic turn' in the last twenty years. Indeed, the transformative fusion of text, image, music and sound are examined in types of transfer that cross genres, time and cultural spaces (Milton 2009; Venuti 2007). Adaptation has always been a core component in the study of transfer involving text and (moving) image, as well as in the examination of the cultural specificities, power relations and actual behaviour affecting such transfer, say, in postcolonial contexts, conditions of mass production, censorship and fan/audience co-authoring.

The field of adaptation studies bears some similarities to translation in that it promoted the study of a derivative product, which was often dismissed as inferior in relation to its source. The initial focus on how narration changes in these derived products allowing them greater or lesser degrees of fidelity to originals was replaced by more inclusive and exploratory pursuits. Thus, the scope expanded at an impressive rate to go beyond the revisited novel-to-film type of adaptation. Today, the priority is to try and understand as many adaptation phenomena out there as possible and to include processes of (co)creation and audience engagement (Hutcheon 2013; Stam 2012). Interestingly, translation is rarely mentioned, and when it is, it is used as a metaphor of adaptation or seen as a peripheral, mechanical step in the process of production (Chan 2012: 413).

This paper aims to contribute to the ongoing debate on 'translation as adaptation' in two ways: by examining an original form of adaptation and by interrogating the theoretical possibilities for the study of humour translation.

On a 'visibility' level, the paper sheds light on a form that is rather underresearched: the adaptation of comedy playtext to comic books. Aristophanic comedies are taken as adaptation exemplars; one may add, exemplars par excellence, because they are texts belonging to an ancient tradition and they have been subjected to a very long process of textual interpretation and performance. Thus, they are bound to highlight discrepancies or links between tradition and modernity. Understanding the creative possibilities in this type of adaptation may require taking a closer look at the narrative components of comics; this is one of the many aspects that have been systematically developed by the nascent field of comics studies, an area still in search of a 'road map' negotiating best synergies between practice, history, aesthetic fandom and methodologies of study (Jenkins 2012: 5).

On a theoretical level, this paper proposes a model for examining the transfer of humour in the translations of comics. As will be shown, the humour of Aristophanes has distinctive satirical, parodic and performative elements which may require creative solutions within the multimodal narrative environment of the comic. The question of how innovative or subversive the transfer of this humour is depends on the interpretive frame deployed by a translator. Their interventions may support the assumption that translation is a significant, creative component of the adaptation process rather than just a mechanical step. 


\section{Long moments of genre transformation}

The words 'comic' and 'comedy' derive from the ancient Greek word "komos," the fusion of dance and song that brought together communities of revellers who honoured the god Dionysus (Xypnetos 1995: 117). Comedy's origins are thought to be 'adaptations': a medley of random scorn present in earlier literary forms (iambic/epic poetry) and the teasing, dance and revelry of social gatherings or structured religious rituals (Xypnetos 1995: 47, 78, 80). Comedy reached its peak in the $5^{\text {th }}$ century BC, developing into a 'comic business,' as playwrights took part in competitive stagings in order to gain prizes (Revermann 2006: 23).

The ritual roots and competitive aspect of comedy plays have shaped both its overall structure and the type of humour therein. Aristophanes, who embodies the apogee of the genre, employs a staggering array of comic devices: verbal humour (puns, coinages, metaphors, idioms, dialects, repetitions and absurd turn-taking); obscenity and indecent acts; slapstick comedy; comic characterisation and unexpected changes in plot or character; disparaging or parodic references and metatheatrical comments (for example, breaking of the theatrical 'frame' by meddling with the props or by using a character as the poet's mouthpiece) (Ewans 2010; Mantelli 2007; 2013; Robson 2006; 2011; 2013).

The matrix that typified the expression of this variety of humour included a prologue, the chorika (chorus parts), episodes, a parabasis (going aside) and an exodos (departure) (Xypnetos 1995: 134-150). In the prologue an actor introduced the play and announced the arrival of the chorus. The chorika were songs, gestures, dance and words performed by the chorus, who occasionally mediated between opposing parties or even provoked them to argue. Episodes contain dialogues between actors, usually embedded in scenes of agon, a debate or competition between characters. Finally, the exodos was the final procession departure of the chorus and actors from the stage. Some comedies were also divided into two parts through a parabasis, an interlude unrelated to the plot, which allowed the playwright to use a chorus lead or a character to express personal views, attack people and institutions, or simply selfpromote.

Theatre productions, be they ancient or modern, adapt the playtext in controlled environments of (collaborative) practice and interpretation. Thus, there is a move from a script (containing directions, clues, guiding deictic terms, descriptions, etc.) to the visual and acoustic modes; (para)language, gesture and proxemics play a pivotal role as to how the performed text will be received (Revermann 2006: 39). Everything becomes meaningful within the specific framework of this adaptation. Actors interpret a role by adopting specific enunciation or gestures, audiences are prepared to notice props or other signs based on their background and directors envisage specific interactions between physical and dramatic space. Comedy capitalises on these typical characteristics of live performance, as well as on unpredictability in the nature and timing of language (for example puns), plot logic, characterisation and spatial practices to create humorous effects (Revermann 2006: 129).

The modern afterlife of Aristophanes' works shows exactly how adaptation lies at the core of performance, also serving as a barometer of social mores and professional practices. Adaptations for the Modern Greek stage from the late $19^{\text {th }}$ to the end of the $20^{\text {th }}$ century plot a long line of gradual acceptance and commercialisation. In 
the early $19^{\text {th }}$ century, Aristophanic reception started with marginal translations by intellectual elites who toned down offensive passages (Van Steen 2000: 25). By the end of the $19^{\text {th }}$ century folk(ish) reimagings of Aristophanes started in earnest. The very first performances were creative paraphrases relying on simplified language, characters and imagery and they tapped into the satirical potential of the plays to criticize the monarchy (Van Steen 2000: 56). Anachronism was thus born. The early $20^{\text {th }}$ century saw openly anti-feminist productions in gentlemen-only venues. Sexual play and sexual confusion in these semi-pornographic adaptations expressed the anxieties of patriarchal professional and social communities (Van Steen 2000: 80; Van Steen 2002: 411). In the late 1950s, gender-neutral productions for the National Theatre focused more on bold anachronisms to reject right-wing Cold War discourse, a quality that was carried over to political gesturing under the dictatorship in the 1970s (Van Steen 2000: 131). The return to democracy and the 1980s saw a wave of further popularity partly enabled by the institution of open-air festivals; an ensuing commercialisation of Aristophanic comedy created a sense of fatigue and uniformity but this did not stop formal experimentation (Brechtian techniques, for instance) and the pursuit of authenticity through bold anachronisms (say, pacifist agendas and political scandals) (Van Steen 2000: 214-217).

Perhaps as part of this general reinvention and formal experimentation we can include the Greek adaptations of Aristophanes' plays to the comic book format, which started in 1981 with the collaboration of Tasos Apostolides and Giorgos Akokalides. ${ }^{1}$ Apostolides is a mathematician and creative writer who now works in secondary education; he has written humorous, satirical columns for various newspapers and taught creative writing for comics in private schools. Akokalides has worked as a political cartoonist for newspapers and continues to work as an illustrator for children's books. The adaptations they created in the early 1980s were extremely popular. As Akokalides and Apostolides state in the afterword to their work, to their surprise, adults avidly read the adaptations. Since their inception, the comics sold over 750,000 copies in Greece, received numerous prizes and were brought out by various publishing houses. The latest cycle in this impressive Aristophanic afterlife concluded in 2012. Metaichmio Publishing (specialising in literature and educational publications), relaunched the Aristophanic comics through their own PC/android-friendly application (Metaichmio (C) and made translations available into English, German and French.

This paper focuses on two comics for reasons of feasibility and thematic. All of Aristophanes' eleven comedies have been adapted, but only five have been translated into English (Frogs, Peace, Assemblywomen, Thesmoforiazusae and Archanians). Of these, Assemblywomen (comic title: Assembly of Women) and Thesmoforiazusae (comic title: Ladies' Day) are thematically related as they both use role reversal to comic effect. The plot of the original plays can be summarised as follows:

Assemblywomen starts with women feeling frustrated with the way men govern the city of Athens. They disguise themselves as men, infiltrate the Assembly and vote in favour of the vision of their leader, Praxagora. Praxagora's husband, Blepyrus, dressed in his wife's clothes (because he cannot find his anywhere), is informed by his friend Chremes that women are now in charge. Praxagora returns to her husband dressed as a woman this time, feigning ignorance. Blepyrus informs her about the vote and she develops her programme: establishing a state where property and wars 
are abolished, where food and sex are communal. The play ends with a series of scenes where the new measures play out. A 'good' citizen wishes to donate his property to the public fund while a sceptic is less willing to do so; a young man who wishes to meet his beloved is forced to sleep with three ugly old women first; and, finally, Blepyrus is asked by a servant to join the communal feast.

Thesmoforiazusae starts with the poet Euripides worrying that women are planning to harm him. Euripides and a relative of his, Mnesilochus, try in vain to persuade the effeminate poet Agathon to infiltrate the 'women-only' festival of Thesmoforia as a spy. Mnesilochus decides to disguise himself as a woman and carry out the plan. Once at the Thesmoforia, Mnesilochus challenges women about their ways and tries to persuade them to let Euripides be. Then Kleisthenes, another effeminate man, reveals Euripides' plan to the women triggering a search for the spy. Mnesilochus is discovered and held hostage. Then Kleisthenes reports Euripides' actions to the male Assembly, who send archers to guard the prisoner. Finally, Euripides is reconciled with women and uses a succession of tricks - parodies of his tragedies and seductive female companions- to free Mnesilochus.

The following section will show how these two plays have transformed to satisfy the requirements of a new medium.

\section{Comic transitions}

Adaptation can be defined as a type of storytelling, a potentially recognisable transposition of previously existing material to a different medium and genre. As such, it constitutes a highly creative and interpretive act of aligning 'material' with a new context of reception. The end product of adaptation offers a lease of afterlife whilst still retaining some intertextual links to its source. Hence translation is unsurprisingly often evoked as a framing metaphor in adaptation studies. Just as there is no such thing as a perfect match between source and target language in translation, so too the hypotext integrated in an adaptation is subjected to various types of integration and addition, omission, condensation, concretisation in (moving) image/action and reculturalisation (Hutcheon 2013: 16; Stam 2012: 80). Such interpretations may affect the portrayal of characters and their motivations, point of view, plot and the ordering of specific events, the sociological, ideological and cultural information of the fictional context, imagery and overall tone (Dudley 2012:70, Hutcheon 2013: 10, Stam 2012: 84-85).

The above issues have been selectively examined in studies that focus on novelto-comics adaptations. For example, Bergman examines the adaptation of The Girl with the Dragon Tattoo into a graphic novel. Her discussion suggests that narrative selection and condensation have occurred. The crime subgenres and political/feminist overtones present in Larsson's book were simplified (Bergman 2014: 105). Also, there is a less nuanced characterisation of Lisbeth Salander, whose motivations schizophrenically gesture to both the Scandinavian novel/film and the American film (Bergman 2014: 99, 101). This is reinforced by visual attributes and visual narrative techniques such as close-ups, all of which help portray Salander as a rebel and an outsider (Bergman 2014: 96, 101).

Even more relevant are studies focusing on the pedagogical uses of Shakespeare's tragedies. Here a mixed audience of variable Shakespeare comic formats may find 
relevance and subtexts of their own, depending on their familiarisation with format conventions and their age. These adaptations aim at simplifying language in the originals and boosting the entertainment function for a younger audience. Hayley (2010: 273) and Sabeti $(2014:$ 185, 187), for instance, show how manga re-imagings of Shakespeare's plays allow transpositions to futuristic settings, heavily condense the plot but simultaneously rely on the rich visual language of manga and on close-ups in order to amplify the motivations and emotions of specific characters. Similarly, Perret (2004: 74, 82-86) highlights further interpretive acts: events are amplified through panel design and sequencing, the plot is restructured so that it becomes coherent, explanations (e.g. footnotes) and visually rich panels may add to the complexity of the setting and characterisation may be affected by verbal modifications and visual interpretations.

To my knowledge, Kalkane (2006) has contributed the only study of Aristophanic play adaptations. In her work she specifically looks at the emergence of comics in the wake of picture-book adaptations, with both genres marking a phase of popular appeal. Later Kalkane looked at how episodes and individual scenes in the eleven comedies by Aristophanes have been freely adapted in comics. She shows that the main characters are retained and that a more accessible and varied register is used (2011: 115). The educational function of the comics depends on these modifications. In addition to simplifications, there are added explanations about ancient Greece (footnotes), plus a structural motif with ideological ramifications that Kalkane calls 'theme-plus-commentary' (2011: 116, 117, 118): an initial utterance by a character is commented on by others, usually within the same panel, and usually in order to portray an oppositional view. Kalkane argues that this might be traced back to the motif of the agon, or oppositional speeches present in classical comedies. As I will show below, there may be additional types of such super-condensed narrative motifs.

Kalkane also notes that the most significant comic mechanisms are those of anachronism and parody. Visual and verbal anachronisms, usually conveyed through culture-specific items, abound in all eleven comics (2011: 120). Parody seems to further bolster anachronistic humorous effects. For example, in Knights, Clouds and Thesmoforiazusae there are parodic references to the discourse of mass protests, professional groups and the feminist movement respectively (Kalkane 2011: 122). In fact, any reference to modern Greek life is a potential candidate. The period ranging from the return to democracy (mid-1970s) to the left-of-centre governments of the 1980s offers a pool of well-codified cultural and political repertoires (Kalkane 2011: 121). Parody adds to the joy of deciphering clues in the text or even creates critical distance from political institutions and everyday habits (Kalkane 2011: 121).

Translation of the above comics into other languages may require further reculturalisation for audiences with different presuppositions, an issue I will discuss in the next section. At this point I would like to examine adaptation as a shift from a 'telling' to a 'showing-with-some-telling' mode, to paraphrase Hutcheon. Crucial to the transition from fiction or script to comics is the change in narration enabled by the medium of comic art. Comics provide a storyboard of performance, where iconic, indexical and symbolic means of expression are combined, for which I would like to use the metaphor of metabase, or transition. The term can refer to the long chain of intertextual and intersemiotic linkages that have led to the comic form, often involving translation proper from the Ancient Greek. Also, the term metabase alludes to 
parabasis, the out-of-frame narrative interlude of ancient Greek comedy where the voice of the playwright was foregrounded. In comics, the entire medium offers points of contact with its creators, as the creators' voice cannot be separated from the form of the comics. I will explain by referring to Lefèvre's continuum of narrative make-up in comics, which, in my view, can also be repurposed to locate and discuss adaptations: format and drawing style, verbal-visual combination, mise en scène and framing, découpage (breaking down of action into panels and page layouts) and plot structure (Lefèvre 2000: online; Lefèvre 2011: 14; Lefèvre 2012: 72-73).

The format of the Aristophanic comics is a standard comic book format not unlike that of Asterix comic books. The e-book version can be adjusted for size, but the upright format $(28 \times 21 \mathrm{~cm}$ in the hard copy version), the average number of panels per page (7.1) and the target audience age mentioned by booksellers (12-14 years) all indicate that the comics are designed to be read quickly. There is a noticeable slowing down in the e-book Metaichmio application as (half)page-by-page reading rhythm is dictated by scrolling. This prevents an instant absorption of action across pages, which is usually the case with hard copies. As a concretisation of the playtext, and drawing style is rather homogeneous, except for colour contrasts and blurred focus when comic tone or the psychological state of individual characters is foregrounded. In all other cases, thick drawing lines, contour lines and a relatively high degree of stylisation are used to distinguish objects, characters and groups of people. Settings are realistic and the action occurs outdoors or near/inside architectural spaces which are depicted in natural proportions and with plain features. The predilection for realistic settings, according to the creators' afterword, highlights the diachronic nature of the work.

Each comic has its own unique verbal-visual environment and its creators may choose to adapt the visual and verbal matter in different ways to respond to the needs of each story. The linguistic matter of the comics is arranged in speech and thought balloons, onomatopoeic paralanguage, narrative captions and footnotes. Balloons vectorise reading, indicating reading direction and time/moments that readers should pay close attention to (Groensteen 2006: 81). In the comics examined here, a relatively uniform type of font and a welter of linguistic styles are employed, which affect characterisation. Fonts feature standard variations in size to indicate emotion, intensity/pitch as well as dialects. In terms of quantity, Assembly of Women has more balloons in total (791 balloons) than Ladies' Day (595 balloons). Assembly of Women also features greater variation of balloon shape and size, therefore routinely containing more text than in Ladies' Day. For example, in busy scenes where Praxagora starts legislating and counters opposition at the Assembly, there are 20-25 balloons per page, usually radiating out from the centre or from specific corners in each panel. The text can be read in any order in these busy panels. A similar density of balloons occurs in the chaotic Thesmoforia meeting and the role-playing sections of Ladies' Day (1923 balloons per page). However, in Ladies' Day balloons are arranged more linearly and special fonts are used to indicate role-playing (see Example 4a/4b, section 4).

Obviously, the language works along the visuals. Overall, the language of the comics tends to be accessible because there is a dual target audience of children and adults and the purpose of the adaptation is to entertain, satirise and educate, as is stated in the paratexts. However, accessibility does not compromise variety. Register is used strategically throughout. For example, the Scythians guarding Mnesilochus 
(pp. 40-42, 47-50) in Ladies' Day are 'othered' in two complementary ways: not only are they visually crude (blank look, small heads, aggressive postures) but they also use a mixture of nondescript central/northern Greek dialect (extensive vowel elisions, Salonican lexical items), dotted with stereotypical phonological and grammatical mistakes that learners of Greek as a second language might produce (e.g. replacing fricatives with plosive stops $/ \theta / \rightarrow / t /$; incorrect use of nominative and accusative). ${ }^{2}$ Language-image incongruities are also used, usually by juxtaposing modern sociolects with ancient settings. This is the case when obfuscatory legalese is used by an adjudicator in Ladies' Day (pp. 40, 43).

As a medium of adaptation, comics are overtly narrative, so the visual-verbal combination may be guided by the voice of the narrator, which manifests itself in three different functions of captions and footnotes:

a) contextualisation/educational function; the narrator frames the plot by providing information on the context or on culture-specific items of the ancient universe the comic portrays. Ladies' Day focuses more on this function (10 footnotes and 10 captions) because references to the ancient festival of Thesmoforia and Euripidean parody must have required explanation; Assembly of Women features just one footnote;

b) scene changers; captions signal the change of space/time. Assembly of Women features more scene changers than Ladies' Day (13 and 8 respectively), because the former is slightly longer, with a more complex plot;

c) playful interactions with the audience; the narrator perhaps mimics what in the original may have taken the form of comments by the chorus or by the poet in the parabasis and comments on the story world; 4 captions and 3 footnotes in Assembly of Women and 2 captions and 2 footnotes in Ladies' Day (hereafter referenced as AW and LD) serve this function. In the above interventions, the narrator's voice sometimes becomes rather salient, creating or reinforcing a humorous tone. For example, a footnote that explains who Agathon is describes him as "A known 'showman'[English loan word] of the time" (LD/9, my translation). Similarly, the narrator may comment on individual characters and their lack of cleverness ("Now he got it"; AW/42) or create funny metalinguistic points of contact: Modern Greek phrases uttered by characters are often back translated into ancient Greek; these are readily recognised fixed expressions that have survived in Modern Greek till today.

Mise en scène and framing play an equally important role in comics. The former refers to the representation of a scene by organising characters (how they are dressed, their bodily presentation), props and decor while the latter is the perspective on a scene, including the shape, size and angle of the frame (Lefèvre 2012:73). In this sense, facial expressions and the manipulation of borders may directly convey aspects of characterisation, point of view, and even ideological implications. Wide frames are reserved for scenes with many characters and speech balloons, or, alternatively, for single characters when there is a need to mimic the slowing down of time. For example, Mnesilochus' arrival at the place of the Thesmoforia (LD/19) is represented with two consecutive wide, panoramic frames that contain no text. Readers can therefore appreciate the centrality of the moment, as well as the absurdity/incongruity of this character's presence in an all-female festival. Other props are used strategically in order to provide anachronistic glimpses. Clothing, accessories, hairdos and objects of consumption in cafés or other public spaces (e.g. coffee, sunbathing products) are clearly modern. 
The two comic books routinely employ medium to long shots and slightly oblique high angles for all action. Close-ups with matching facial expressions are reserved for (main) characters who experience intense emotions such as fear or anger (Mnesilochus LD/31-33, 40; Praxagora AW/41; young/old woman AW/43), characters who deliver significant ideological content in speeches (Andromache LD/23; Praxagora AW/32-37) or secondary characters who appear as confused or stupid (Scythians $\mathrm{LD} / 47,48,50)$. Close-ups are also reserved for secondary and main characters whose interventions are associated with a hinge in the plot, as is the case when Kleisthenes (LD/29) announces that a man is hiding amidst the assembled women and he suggests that ID cards [sic] be checked.

Perhaps an idiosyncratic use of close-ups can be seen in Aristophanes' cameo in Assembly of Women. In the final four panels, for example, a close-up of Aristophanes delivers a eulogy of women's ascent to power (AW/50). In three other places, Aristophanes appears as an observer over consecutive panels, starting from a proximal point-of-view shot (back angle) and then presented in distant, top-left, high angle as an observer $(\mathrm{AW} / 6-7,21)$. Then there is one more instance whereby the motif is repeated slightly changed, with a point-of-view angle and then a horizontal frontal angle:

FIGURE 1

Aristophanes 'cameo' (AW/21)

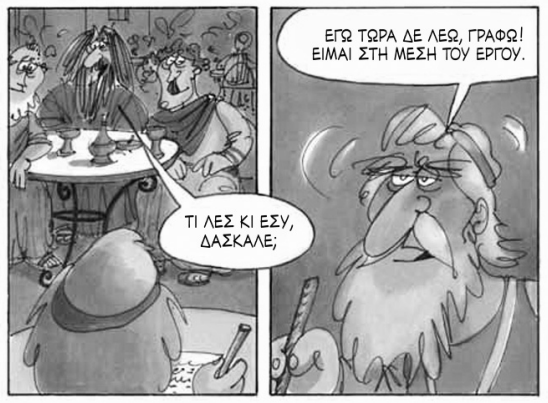

This time Aristophanes speaks. When asked by men what he thinks about women's advantages over men he replies: "Now I do not speak, I am writing! I am in the middle of the piece." (Figure 1, my translation). The combination of visuals and verbal elements in such framing establishes a super-condensed recreation of meta-theatrical conventions. Assembly of Women is one of the few comedies that does not have a parabasis and the frame on p.21 is almost halfway through the comic (45 pages in total). Here Aristophanes' voice is concretised and visually foregrounded.

Mise en scène and framing combined may create a certain visual rhythm which is indicative of the book's découpage, the way in which the story is broken down to panels and pages (Lefèvre 2011: 17). For example, readers can experience regular and irregular number of panels per page and panels on each row forming sequences of strips. This alternating visual rhythm is significant for the plot, as a page-turning effect can be created when actions or moments spill over pages. It is also ideologically important, because irregularity can signal disorder, opposition or subversion. Finally, it creates a dual aesthetic effect: on the one hand chunks of comic material are 
perceived as part of a symmetrical, unified whole and readers stop to absorb information instantly, while on the other, they direct reader gaze from panel to panel and from page to page (Molotiu 2012: 89, 91). Assembly of Women features more of this sequential energy, because framing and cross-panel transitions are more varied. For example, inset panels and low angles are systematically used to indicate that women are now on top, refuting those who doubt them and finding practical solutions for the body politic. Figure 2 below shows one among the many panels of this kind. It is a pink inset panel where Praxagora promises to safeguard her new order. Groups of men around her discuss, echoing her left-wing proclamations (e.g. references to 'Praxist government,' 'communal property,' 'nationalising' etc.).

FIGURE 2

Praxagora's speech $(\mathrm{AW} / 37)$

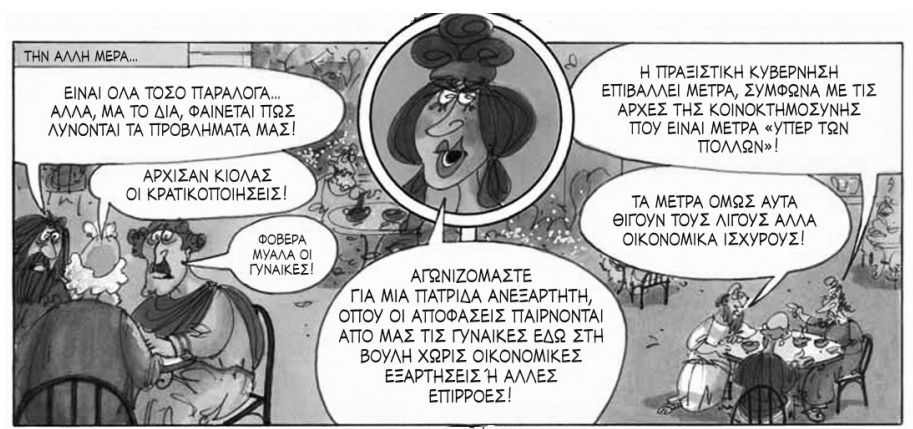

Clearly, the overarching function of découpage is that of serving the plot. Via the plot the reader reconstructs the fabula (chronological unfolding of events) and the medium itself may or may not serve linearity in time through temporal and spatial succession of panels and the simultaneous presence of various speech balloons and panels (Lefèvre 2011: 20, 23; Singer 2012: 59). Whilst ambiguity of time is not an issue in the two comics at hand, events are juxtaposed to create funny incongruities. An apt example is the constant cross-cutting between Praxagora's first speech at the Assembly as a man in disguise and Blepyrus wearing a dress and trying to deal with his sudden constipation problem. Over three pages (AW/pp.18-20), five strips are arranged with one big 'Praxagora panel' on the right and two small 'Blepyrus panels' on the left, plus one balanced (1-1) strip on either end of this découpage. The excerpt below concretises a funny obstetrics image: Blepyrus evokes the goddess of labour to free him, whilst Praxagora also gives birth to her subversive plan/idea for women in government. This incongruity between a public event and a very private bodily function also constitutes a concretisation of obscenity, amply present in lines 311-371 of the playtext (1993 translation $\left.{ }^{3}\right)$. 
FIGURE 3

Humorous cross-cutting (AW/20)
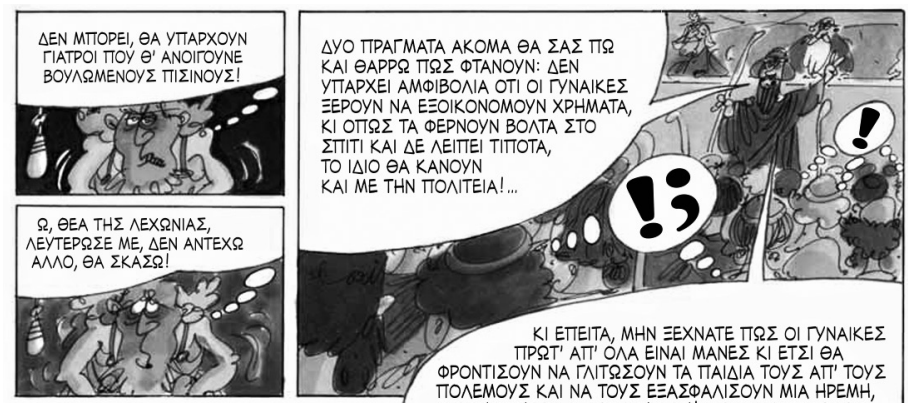

Generally, the most prominent change the plot is subjected to is that of condensation, as playtexts of roughly 120 pages are rendered in 45 pages in the comics. The 1,181 lines of Assemblywomen are adapted to 357 panels and the 1,231 lines of Thesmoforiazusae are delivered in 312 panels. Assembly of Women keeps all episodes and scenes, occasionally condensing scenes slightly. The fourth episode in the playtext, for example, consists of 377 lines distributed over three scenes, which is rendered with 87 panels, distributed roughly in the same way (e.g. the second scene takes up $62 \%$ of the playtext lines and $58 \%$ of the panels in the comic).

Ladies' Day, on the other hand, loses a whole episode where Mnesilochus, in his desperate attempt to evade capture, takes what he thinks is a baby as hostage only to find out it is a bag of wine (lines 728-784). The episode is a parodic reference to Euripides' tragedy Telephos where Orestes snatches a baby and threatens to kill it at the altar unless his demands are met. The deletion here may have been motivated by the violent topic or by the specificity of the allusion on which the episode relies. Ladies' Day also loses two scenes that brim with bodily descriptions and obscenity: the scene of Mnesilochus' transformation to a woman (prologue, lines 210-265) and part of his recognition by Kleisthenes and his female gang (episode one, lines 618650). Partial compensation for the latter may be found in two consecutive panels where the gang disrobes Mnesilochus, leaving his naked buttocks exposed (LD/32).

It is beyond the scope of this paper to present a comprehensive list of all the modifications, omissions or additions that have taken place in the two comics. The most salient changes, however, concern the creative way in which omissions are handled. Thus, all chorus components and the parabasis have been jettisoned. Perhaps these sections were not functional or interesting enough. The 'footprint' of these structural components is occasionally covered by vestigial compensations and modifications. In parts where the chorus played a significant role, other characters take up this role (for instance, Kleisthenes orders the search in Ladies' Day). An omitted parabasis was also recreated in the super-condensed cameo role of Aristophanes in Assembly of Women mentioned above. This comic also contains a vestigial recreation of chorus elements in a single page where a day in a woman's life who juggles politics, children and the new sex laws is recounted in rhyme (AW/39). The docu-soap type of introduction in the caption for this sequence and the personal narrative of the woman becomes an interlude, not unlike that in the iambic/choric parts of the original play.

Unfettered by the constraints of a typical comedy structure, the creators also have directorial freedom to distribute roles as they see fit. Again, the comic medium 
offers opportunities for regularity and creativity. As the table below shows, there is flexibility in protagonist visibility:

TABLE 1

Protagonist visibility

\begin{tabular}{|l|c|c|c|c|c|}
\hline Material & Assemblywomen & Thesmoforiazusae & AW Comic & LD Comic & Total value \\
\hline Praxagora lines & $416(35 \%)$ & & & & 1,181 \\
\hline Praxagora balloons & & & $114(14 \%)$ & & 791 \\
\hline Praxagora panels & & & $108(30 \%)$ & & 357 \\
\hline $\begin{array}{l}\text { Blebyrus } \\
\text { lines }\end{array}$ & $202(17 \%)$ & & & 1,181 \\
\hline Blepyrus balloons & & & $121(15 \%)$ & & 791 \\
\hline Blepyrus panels & & $365(29 \%)$ & & & 357 \\
\hline Mnesilochus lines & & & & $107(17 \%)$ & 595 \\
\hline $\begin{array}{l}\text { Mnesilochus } \\
\text { balloons }\end{array}$ & & & & $121(38 \%)$ & 312 \\
\hline Mnesilochus panels & & & & $96(16 \%)$ & 595 \\
\hline Euripides lines & & & & $119(38 \%)$ & 312 \\
\hline Euripides balloons & & & & 51 (17\%) & \\
\hline Euripides panels & & & & 595 \\
\hline $\begin{array}{l}\text { Aristophanes } \\
\text { balloons }\end{array}$ & & & & 312 \\
\hline $\begin{array}{l}\text { Aristophanes } \\
\text { panels }\end{array}$ & & & & & \\
\hline
\end{tabular}

All main characters are kept and their actions, motivations and emotions become the focus of the reading experience. Unlike the playtext, the comic is very balanced in terms of how visible protagonists are on panels or how much they express themselves in balloons. For example, the configuration of balloons (16-17\% of the total) and panels (38\% of the total) corresponding to Mnesilochus and Euripides mirror each other; a similar normalising effect can be seen in the proportion of visibility afforded to Praxagora and Blepyrus. There are also some interesting additions. Aristophanes, for example, becomes a character in Ladies' Day. Rather than bringing the plot forward, his actions concretise meta-theatrical conventions, this time from a reverse narrative point of view. Aristophanes, the satirist of Euripides, self-effacingly admits he has unjustly fomented women's hatred against Euripides. Thus, he tries to redeem himself and comes across as helpful and sympathetic.

\section{Translating humour}

Just as adaptation is a metabase or transition from the playtext, so too translation, in practical terms, is a further metabase. The network of translated Modern Greek texts, and performed theatre plays formed the backdrop against which the comics were created. Thus, translations are the most recent step in a long chain of intertextual relations, allowing the adapted works to be aired in the public domain in various languages. An obvious issue in interlingual metabase is the effective transfer of humour. This is the case even in traditional, literal translations from the ancient Greek. For example, Stavrou, whose Modern Greek translations the comic creators consulted, 
notes that his approach is based on avoidance of anachronisms and on respect towards the content as well as the form of the originals; the exceptions where more distance needs to be gained are rhythm/poetical conventions and humour (Stavrou 1967/2010: 27-28). This paradox of remaining faithful to the original by rewriting the target text is constant in any discussion of humour in general (Attardo 2002; Zanettin 2010) or of Aristophanic humour in particular (Ewans 2010; Robson 2006).

A frequently used model for the general discussion of humour is Attardo's General Theory of Verbal Humor (GTVH). Briefly, the model suggests that jokes depend on incongruous knowledge representations (scripts) which are realised on the following levels: language (phonetic, semantic, pragmatic levels of the joke), narrative strategy (the joke telling), target (or butt of the joke), situation (objects, participants, activities), logical mechanism (the logic of the joke, e.g. role reversal, ignoring the obvious, etc.) and script opposition (conflicting interpretations) (Attardo 2002: 176-178). GTVH was initially devised for the study of verbal jokes and, later, to gauge joke similarity across languages. The model has also been used in the study of humour in Aristophanes' plays by Robson (2011). Without specifically spelling out what the knowledge resources mean in each stretch of text, Robson focuses on the merits of adapting the text and compensating for challenging instances of humour, especially puns (2011: 178).

Attardo's GVTH may capture the specificities of comic books to a greater or lesser extent. Zanettin aptly notes that humour may be traced in verbal and/or visual incongruities and that readers of different formats (one-panel cartoons, short comic strips and long comic books) may respond differently depending on comic literacy general background knowledge (Zanettin 2010: 40, 43-46). Yet his discussion is influenced by a bias towards puns, which is not uncommon in humour research and there is no systematic integration of narrative features. Indeed, rather than looking at specific linguistic features such as puns, it may be productive to take narrative aspects as the starting point for incongruities. To paraphrase Vandaele, the creators of the comics may mediate information, attitudes and emotions in a way that allows a dominant agent of communication to 'denormalise' expectations, values and actions; this potentially leads to comic suspense, comic surprise and comic characterisation (2010: 748, 749, 763). Thus readers may, for instance, appreciate the comic creator's playful break of frame or notice the narrator's distance from/empathy with certain characters. In what follows, I will focus on some prominent adaptations in the two comic books that serve comic characterisation and narrator-reader contact. Given the major themes of the two adapted plays, I would summarise the relevant knowledge resources as follows:

- Script opposition: YOUNG/OLD, IDEAL/REAL, PUBLIC/PRIVATE, PAST/ PRESENT, MALE/FEMALE

- Logical mechanism: false analogies, anachronism, role/gender reversal, exaggeration, repetition, etc.

- Target: men, women, stupidity, Euripides' plays, viewers, social conventions

- Situation: mise en scène

- Narrative strategy: format and drawing style, verbal-visual sequence, framing, events, scenes and the plot in general (if changed), intruding voice of overt narrative sections (introduction and captions)

- Language: text in speech and thought balloons, and captions 
The common introduction used for all the issues of the comics constitutes the most overt intervention of the books creators. This introduction bio is written in a relatively detached, formal style. Content-wise, the bio presents major milestones and the diachronic value of Aristophanes' plays. It profiles him as a staunch supporter of democracy and a great 'teacher.' The above are visually complemented by a drawing of Aristophanes coming out of a theatre, holding a walking stick in one hand and stone tablets and scrolls on the other, mouth half open as if poised to speak to viewers. The English editions feature a first-person 'introduction' as the excerpts below show:

[...] my parents move to Aegina, a nearby island. As it was a rather quiet place, I spent a lot of time reading.

[...] Through my works I tried to promote the principles of peace and democracy, for which, I must admit, I received lots of prizes and acclaim. All right, all right, I know... I also wrote about women, Ecclesiazusae (Assembly of women). But I was old and blinkered then! And it was all the bickering at home that made me do it!...

[...] As far as the adaptation of my work into comic strips [sic] is concerned, there's not much I can say since this genre did not exist in my days! I guess my comedies will be easier to read now, even for youngsters. And that I would heartily recommend!

The text is 'performative,' written in a simple dialogic style. The text creates a PAST/ PRESENT and PUBLIC/PRIVATE incongruity by targeting Aristophanes' temporary lapse from modesty and his married life and by anachronistically referring to the educational value of comics. The rewritten text omits some factual information in order to amplify the narrative function of the introduction. By taking mise en scène into account (Aristophanes poised to speak outside a theatre), the introduction resembles text that would normally be seen in a caption or a speech balloon. This way it helps establish the comic tone of the entire comic book.

In the main body of the comic, the most obvious shift concerns taboo language. Obviously, the comics are rather innocuous in relation to the plays, but they do contain some swearing and derogatory terms. The English translations seem to amplify these. For example, Mnesilochus is called 'old dogface' (LD/p.34), and 'shrivelled dogface clown' in the translation. The translations also contain swearing where there was none in the original. For instance, Chremes' utterance, 'Stop saying stupid things' (AW/p.26) is translated as, 'Now cut the crap and think rationally.' Taboo language in general helps convey the emotions of characters. Often, it is the defining feature of a particular scene. This is the case when a young man becomes the bone of contention among one young and three old women in Assembly of Women. The first old woman refers to Praxagora's legislation, according to which the ugliest woman has the right to claim any young suitor-victim, as follows: 'if you wish to knock on this girl's door, you must first knock on mine!...' (AW/p.45); the translation is bolder: 'If you wanna drink this chick's juices, you must first taste mine.' In a sense, the English translation resembles the playtext (lines 1015-1020 repeatedly use 'fuck' and other synonyms; 1993 translation). The translation portrays a YOUNG/OLD incongruity which gradually builds up, through repetition and exaggeration. The following example marks the beginning of the antagonism between the young woman and the old woman: 
(1)

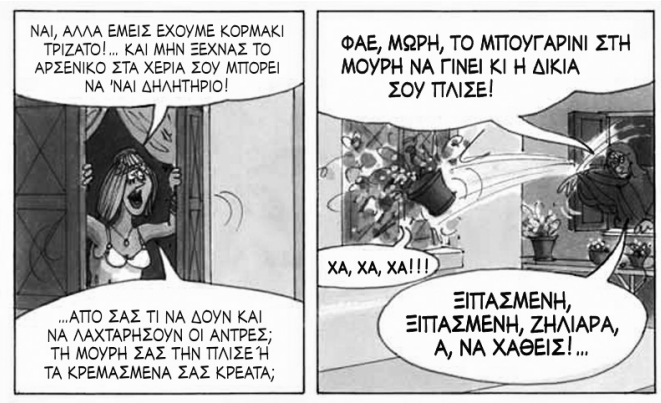

Example 1a: Young/old woman (AW.44)

\section{GLOSS:}

Young woman: //Yes but we have perfect[+slang] body!... and don't forget that a man[pun - arseniko $=$ man/arsenic] in your arms would become poison!//

//...What can men see and crave in you? Your creased mug or your flabby meat[+plural]?// Old Woman: //Take mori[+offensive vocative] the jasmine on your face[+slang] so that it gets wrinkled too!//

//Ha, ha, ha!!!//

//[You]Arrogant, arrogant, jealous, get lost!...//
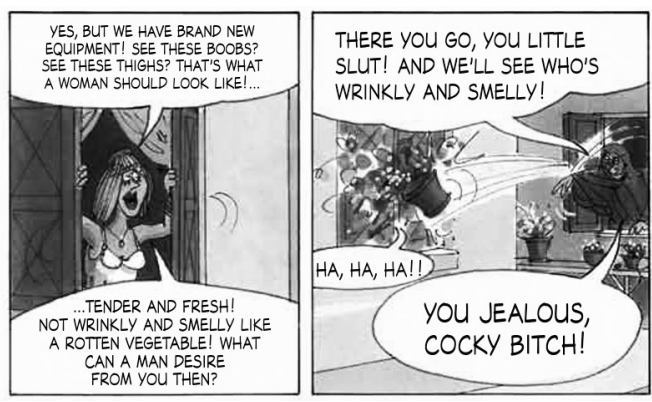

Example 1b: translation (AW44)

The panels feature a cumulative use of metaphor/comparison and false analogies (pert body-decaying edibles, face being wrinkled because of age/physical harm). The target is the old woman who is presented as losing her temper and possibly behaving in an incongruous manner for her age. The two women stand by their windows, where their neighbourly conversation spirals out of control. The old woman features a wizened face, dark eyes and is covered up (resembling old black-clad widows in various parts of Greece). She is presented from the opposite angle to that of the young woman, who wears make-up and shows off her curves in her tight sleeveless top. The text proceeds from showing off and derogatory descriptions in the first panel to physical and verbal violence in the second. The translation makes more direct references to the young woman's sexual attractiveness ('boobs,' in this instance coheres with the visuals) and creatively builds on a metaphor of the body being an edible/fresh plant (or not). The second panel contains a string of cosmetic adjectives uttered by the old woman ('slut,' 'cocky bitch') which are much stronger than the informal, rude vocative mori in the original (which etymologically derives from 'stupid,' but is often used as an 
attention-getting device within peers). Apart from constituting a comic subversion of decorum, the exaggerated antagonism in this scene becomes a sign of the weaknesses in Praxagora's system and a realisation of the IDEAL/REAL script opposition.

Praxagora's movement, or 'Praxism' ('Praxagorism' in the translation) ${ }^{4}$ becomes responsible for various legislative initiatives. An example of this is featured below:

(2)

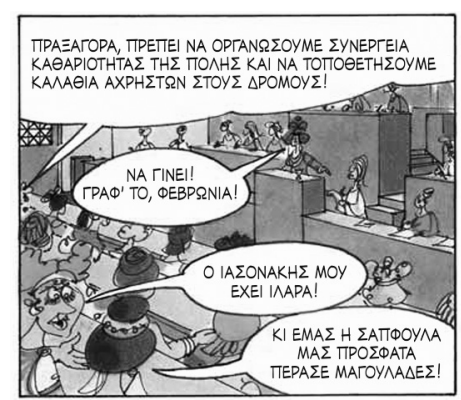

Example 2a: women in parliament (AW/38)

Gloss:

//Praxagora, we need to organise city cleaning agencies and place rubbish bins in the streets!//

//Let it be done! Write that down, Febronia!//

//My Jason[+diminitive] has chickenpox!//

//And our Sappho[+diminutive] recently had mumps!//

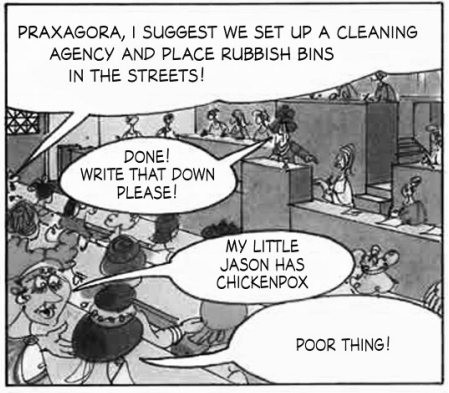

Example 2b: translation (AW/38)

The panel is representative of similar instances of mise en scène where women take part in politics. A PUBLIC/PRIVATE incongruity is created in those panels. As serious polis matters are being discussed in the parliament, secondary characters ignore the obvious norm of leaving domestic issues aside when attending parliamentary meetings (and become targets). These secondary characters are usually shown in very feminine attires. High angles also increase the distance between the reader and the situation portrayed. The text is rendered aptly in most cases, but there is a sense that the translator could have elaborated on this script opposition even more. This is especially salient when the text is edited down as in Example 2b. The resulting translation is narratively coherent, but misses out on an opportunity to build on the above-mentioned comedic technique. 
Feminist reculturalisation is also very prominent in the two comedies. For example, in the first scene of LD, the official version of Thesmoforia is presented as a girly revelry where carnivalesque female bonding occurs (LD/6). The creators of the comic have capitalised on a page-turning effect to create narrative surprise - on p.7 the true version of events is explained:

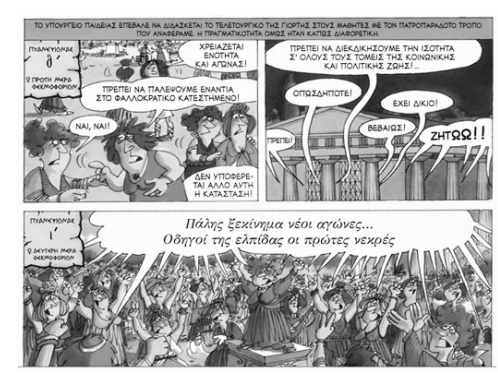

Example 3a: Thesmoforia (LD/7)

\section{GLOSS:}

[caption]: //Ministry of Education has decreed that the ritual of this festival be taught to students in the traditional way that we mentioned. Reality, however is somewhat different.

Panel 1 [caption]: //Pyanepsion 9' 9 First day of Thesmoforia//

//There is a need for unity and struggle!//

//We must fight against phallocratic status quo!//

//Yes, yes!//

//This situation is unbearable!//

Panel 2 //We must claim equality in all fields of social and political life!...//

//We must!//

//Certainly!//

//Surely!//

//She's right!//

//Horray!!//

Panel 3 [caption]: //Pyanepsion 10' + Second day of Thesmoforia//

//The beginning of stuggle, new campaigns... Leaders of hope, the first dead[+feminine]//

The scene is structured around a PRESENT/PAST and PUBLIC/PRIVATE incongruity. The logical mechanisms employed here are those of anachronism and juxtaposition. The situation is that of an organised political event which is masqueraded as a private ritual. ${ }^{5}$ The first few panels of this page feature characters making sombre feminist proclamations. For example, in the first panel, the second balloon states that this is a struggle against 'phallocratic status quo.' Similarly, the first narrative caption

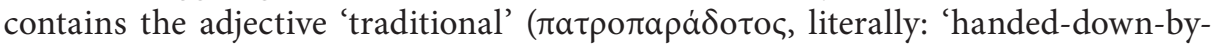
fathers'), a choice reinforcing the incongruity between public male-centred discourse and the political agenda of this covert social event; the anachronistic reference to the Ministry of Education also creates a PRESENT/PAST medley, leaving this institution open to playful critique (target). Captions in panels 1 and 3 put a further feminist stamp on the Thesmoforia visually $(+)$ and pink colouration reinforces the ideological import of the scene. The culmination of revolutionary fervor is framed in panel 3 with a birds-eye-view shot of a woman standing on top of Demeter's altar 
and a crowd of women, some clad in pink, cheering with her. They jointly sing a song performed by Mikis Theodorakis and Maria Farantouri, The first dead (1971). This widely known revolutionary song is used here to bridge the anti-dictatorship struggle of the 1970s with ancient Thesmoforia, and reverses the masculine grammatical gender of the original song to match the visuals. The panel may have a covert target too; the antidictatorship struggle and possibly the left-inspired student movement of the 1970s are potentially being critically parodied, because Greek social movements in the 1970s, although very inclusive, were not particularly feminist.

The English translation does not sound as stylised as the original. Language is more accessible, possibly more fitting to a grassroots movement that the Thesmoforia may be the arena for. The main translation problem in this sequence, of course, is the song, which is replaced by another allusion, Bob Marley's Get up, stand up (1973). Such a recontextualisation allows an equivalent incongruous bridging effect. Ancient Thesmoforia is linked to an international anthem of human rights movements. Digital releases by Amnesty International are known to include this song or use the song title in their advertising campaigns. The allusion is deftly integrated into the mise en scène because women singing in unison are actually standing up.

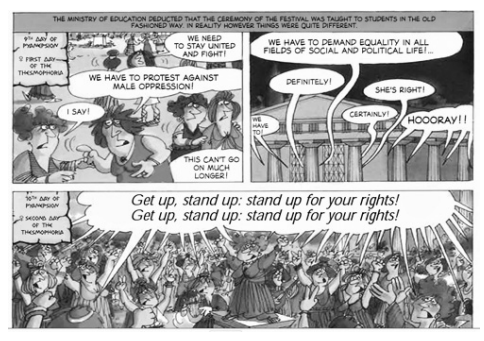

Example 3b: translation (LD/7)

The above ideological shifts link to one of the most functional script oppositions for the plots in either comedy, namely, gender performance (MALE/FEMALE). As Foley (2014: 270) and Van Steen (2002: 424-25) have noted, the playtext offers ample opportunities for gender stereotypes to be expanded or questioned, depending on the interpretive frame that becomes relevant for an adapter (add translator) in a given moment in time. Indeed, the two comic adaptations involve a host of characters with marginal gender identities: effeminate men, complete with present-day make-up, such as Agathon and Kleisthenes in LD. Lesbians, such as the tellingly named 'Lesbiope' in AW and unidentified butch women in LD are interesting additions. Finally, the comics also entail characters with canonical gender identities who resort to transvestism in order to achieve their goals. In what follows, I will focus on how Agathon and Mnesilochus are portrayed.

The translator has manipulated lexical equivalents for camp discourse which have a direct effect on MALE/FEMALE oppositions and characterisation. For example, Agathon's appearance (LD/11-16) (mascara, lipstick, girly hairstyle, sandals and pink dress, slender figure) and his demeanour (graceful movements, hands touching face and hair, standing with hands akimbo, singing) is complemented by

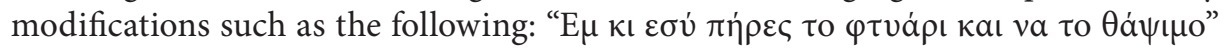
[Well, you took up the spade and there's the burying] features an idiom for 'you 
maligned' ('to bury someone,' in Greek) which is playfully extended; this is rendered as a camped-up statement: "Well, honey, they've got a point! I mean honestly..." (LD/14) (vocative 'honey' and rhetorical routine for complaining 'honestly'). The statement occurs in the scene where Agathon explains to Euripides that negative publicity in his tragedies has caused women to hate him. Agathon then refuses to offer his help to Euripides, noting that women are vindictive and that he does not like them as he endures too much when his showbiz work commitments force him to collaborate with women (LD/15).

By camping up Agathon's language, the translator creates an even more striking incongruity between Agathon, and the other effeminate man of the play, Kleisthenes. From an ideological point of view, Kleisthenes fully identifies with women. He serves their vested interests, something that leads women at Thesmoforia to actually call him 'one of their own' (LD/29). Kleisthenes is more rotund (and probably older) than Agathon and equally camp visually (eye shadow, blush, ear rings, white dress and pink mantle/himation, high heels). However, his (body) language is not feminine and he identifies himself as a man. Interestingly, Kleisthenes briefly appears in Assembly of Women too (AW/33-35), a deviation from the playtext forging intertextual links between the two comics. In this cameo appearance verbal camp is toned down:

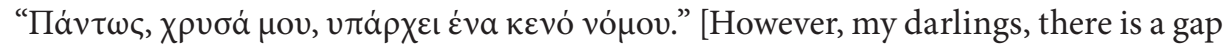
of law] is rendered as, "That's nice and all but I think this law misses a point." (AW/33).

The above shifts in parodic femininity render the image-text relation more striking, they create continuity in characterisation (for Kleisthenes) and, most importantly, they trigger incongruities relating to stereotypes. Agathon may 'pass' as a woman and even present himself as a desirable object of male gaze, but his words reflect misogynist views. Kleisthenes, on the other hand, tries on external characteristics of the female gender, but is less concerned with 'passing.' Just like Agathon, he lives in the company of women but he can freely move in their private space of the Thesmoforia and protects their interests.

A similar, overt intervention can be seen in the final episode of LD where Euripides and Mnesilochus role play Helen in order to escape. The accompanying female guard, Krytilla, expresses her disbelief and threatens them.

(4)

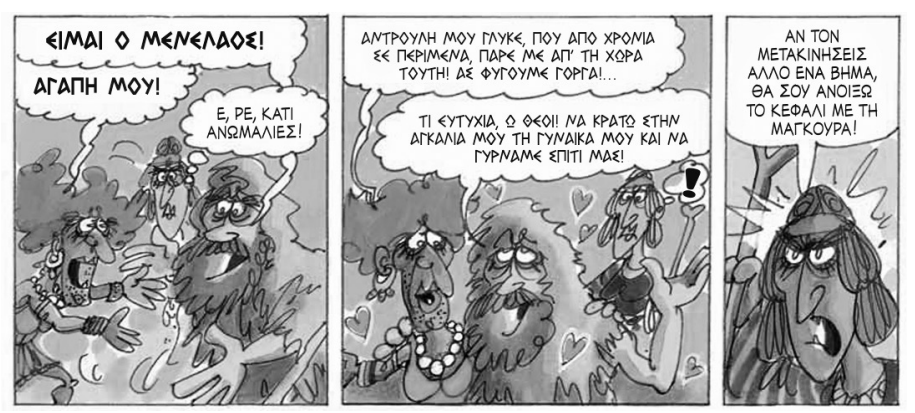

Example 4a: Euripides-Mnesilochus (LD/39)

GLOSS:

Panel 1: //I am Menelaus.///My love!// //Re[disagreement particle] what perversions!// Panel 2: // My sweet hubby for whom I have been waiting for years, take me from this land! Let's leave swiftly!... // // What happiness, o Gods! Holding in my arms my wife 
and returning to our home!// Panel 3: //If you move him one more step, I will open your head with the stick!//

Here the script of opposition is conveyed through a role reversal in what seems to be a recognition scene from a tragedy involving a man and a woman. Narratively, the scene foregrounds the two long-lost lovers with a medium shot, whilst Kritylla can be seen in the background. Pseudo-Helen and pseudo-Menelaus act out their roles in Greek fonts which indicate the allusive nature of their utterances. The conventions behind grandiose reunion scenes in tragedies thus serve as the target here. Kritylla is puzzled after repeated attempts on page 38 to convince Menelaus that this is not a woman, let alone Helen. Her thought balloon in the first panel in Example 4 conveys her scepticism as well as her hetero-normative dismissal of the man-woman scenario as deviant.
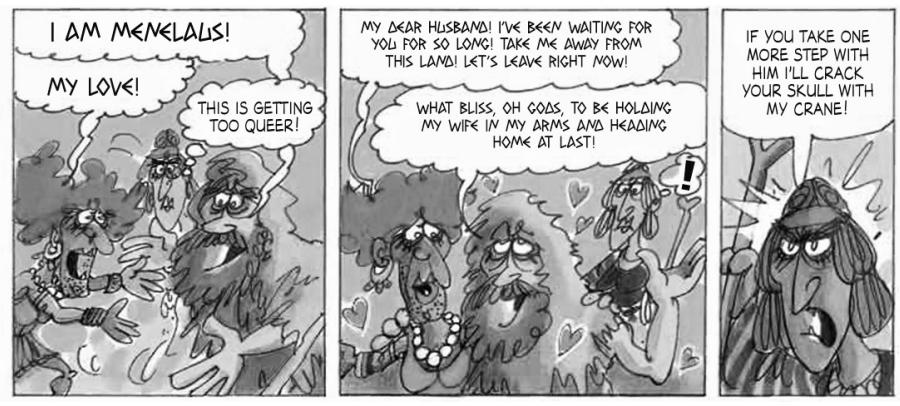

Example 4b: translation (LD/39)

The translation employs the same style of fonts to signal intertextuality. The style of delivery is arguably more stilted ('My dear husband'). The translation hinge in this sequence is Krytilla's thought balloon, which characterises the reunion as 'queer.' This description tallies with the narrative strategy of the panels, which are saturated with a pink background colour and pink hearts. It is an inspired solution as it multiplies incongruities. On the one hand, it sustains a MALE/FEMALE incongruity and a PAST/PRESENT ambiguity by grafting modern gender politics to the text; as a result, it sounds more politically correct than the original. On the other hand, it also serves a meta-theatrical IDEAL/REAL distinction. Just as audiences of ancient (and some modern) performances of Old Comedy were expected to notice visual cues (such as phalluses) and identify the men performing female roles as male, so too Krytilla states the obvious concerning the 'performed piece' before her.

\section{Conclusion}

This article has examined adaptation and translation as part of the same chain in narrative transformations. In light of this discussion, the main points can be summarised in tables 2 and 3 below, which may serve as grids for textual and contextual analysis within and across transfer types. The main focus here was on the close multimodal reading of the highly under-researched Greek adaptations of Aristophanic texts, along with their English translations. However, the theoretical premises and 
procedures of sample analysis captured in the tables below can be readily used for the scrutiny of comedy play adaptations (adaptation studies) or even for a more systematic and comprehensive examination of other genres, including drama (with the proviso that key repertoire elements, underlined in table 2, be modified). They can also be useful for the study of multimodal humour, say, in cartoons and strips or even in adverts that have a sequential structure (humour studies) or in the interlingual transfer of comics (translation studies). Specifically in the case of humour research or its translation, going beyond the more commonly studied area of wordplay, onomatopoeia and proper names, the grid shows that there is a wealth of 'repertoremes' deserving attention and which need to be seen more holistically rather than as items.

TABLE 2

The humour of Aristophanic metabase

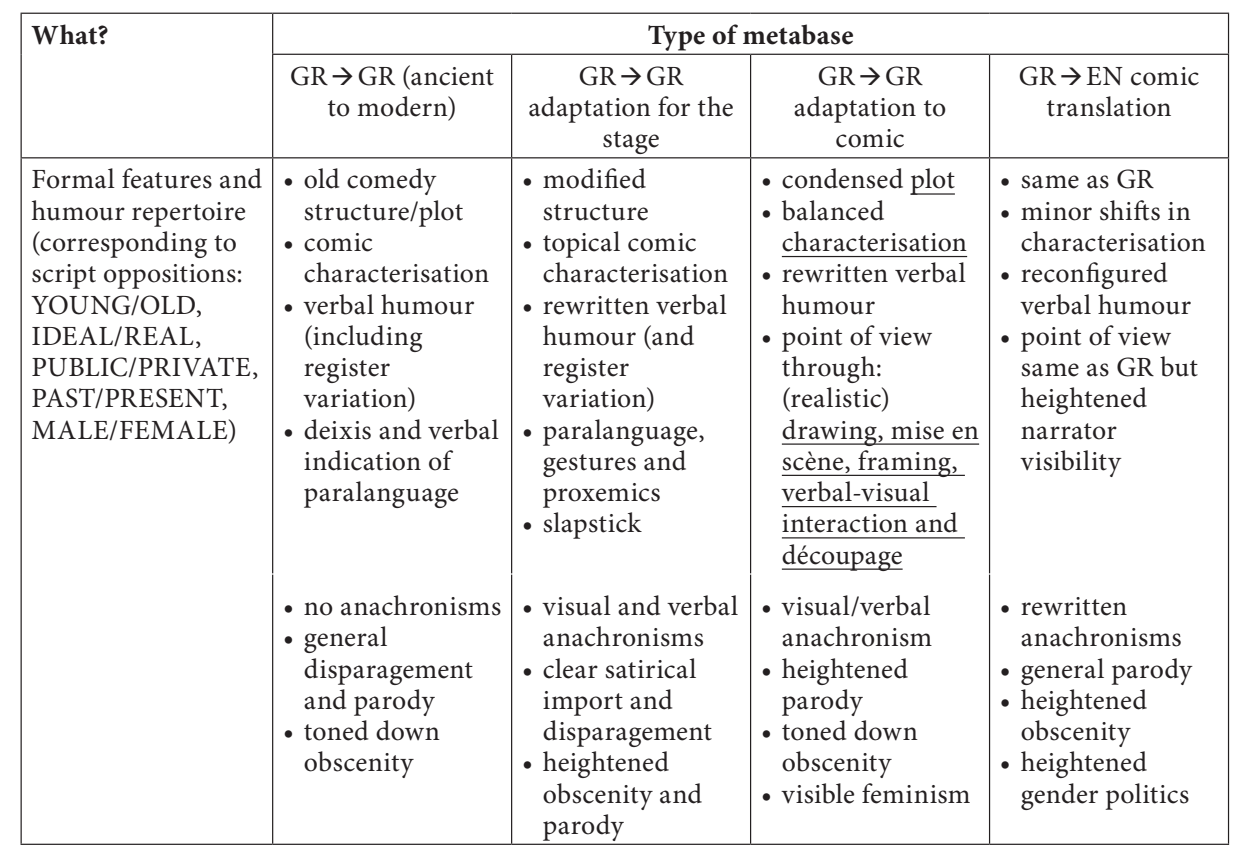

As was shown in sections 3 and 4, humorous sequences in comedy texts comprise (verbal) signs that help realise the specifics of situation and narrative strategy. Thus, they directly feed into the general script oppositions which serve the plot, structure, characterisation and style of that specific genre.

Looking across transfer types, the specific playtext which was consulted by the creators of the comic books is a widely known, poetically faithful and linguistically creative translation produced in the late 1960s. Yet it remained ideologically 'tame' and linguistically sanitised, perhaps serving as a good basis for an adaptation destined for younger eyes. From then onwards, multiple theatre productions consolidated a tradition of increasing the accessibility of the text and of experimentation with register, acting styles and visual props. Jointly, adaptations for the stage exhibited a type of humour that was culturally relevant, playful and overtly satirical. 
Indeed, commercial success of Aristophanic performances to date depends, inter alia, on how topical or subversive they are.

Similarly to the plays, the comic-book adaptations constitute a creative rewriting of comedy. The plot and structure is considerably condensed, the language is accessible and educational explanations are added. On the other hand, the visual-text rhythm, the scene specifics and panel framing help create a complex multimodal environment. There are ample opportunities for funny incongruities (e.g. concrete instances of parody and anachronism), as well as for narrative or ideological emphasis (e.g. framing of speeches, close-ups of key comic moments or plot hinges). A highly interesting innovation here is the super-condensed visual rendering, in single panels, of meta-theatrical commentary (parabasis) and the quasi-cinematic cross-cutting involving incongruous scenes. Finally, there are recognisable panel patterns and a calculated proportion in character visibility, both contributing to the plot and genre recognition as such. As a visual art, comic books thrive on a feature that seasoned comic readers of all ages see and appreciate: symmetry.

The English translation does not feature any change in the layout, plot, or the visuals and the framing thereof. However, there are slight modifications in verbal components. The narrator's voice is made even more visible, most notably in the introduction, which is rewritten in the first person and jettisons factual information in favour of a comic tone. Obscenities are intensified, thus allowing the comic book to be faithful to the spirit of the ancient Greek text (or more daring translations) and to convey character emotions directly. Similar changes in characters can be seen in the way gender politics is expressed. The English translation is, arguably, more politically correct, direct and consistent in the portrayal of gender identities. Finally, parody and anachronisms are recontextualised so that they are general enough to make sense to an international audience. What stands out as a recurring pattern is the translator's conscious attempt to match verbal components with mise en scène specifics. This renewed intersemiotic cohesion in the translation does justice to the multimodal representation of narrative intentions, comic incongruities and all.

Investigating the form (including the adaptation of visuals), content, production, reception and socio-cultural context are ultimate priorities in comics studies (Jenkins 2012: 4) and translation studies (Zanettin 2008: 23). These priorities can be subsumed under a first-level of distinctions covering the type of metabase (medium) and a second-level level covering engagement and externalities.

TABLE 3

The modalities of Aristophanic metabase

\begin{tabular}{|l|l|l|l|l|}
\hline \multirow{2}{*}{$\begin{array}{l}\text { Who, how, } \\
\text { when and why? }\end{array}$} & $\begin{array}{l}\text { GR } \rightarrow \text { GR (ancient } \\
\text { to modern) }\end{array}$ & $\begin{array}{l}\text { GR } \rightarrow \text { GR adaptation } \\
\text { for the stage }\end{array}$ & $\begin{array}{l}\text { GR } \rightarrow \text { GR adaptation } \\
\text { to comic }\end{array}$ & $\begin{array}{c}\text { GR } \rightarrow \text { EN comic } \\
\text { translation }\end{array}$ \\
\hline $\begin{array}{l}\text { Genre and } \\
\text { process of } \\
\text { production }\end{array}$ & $\begin{array}{l}\text { comedy playtext; } \\
\text { modify source } \\
\text { (slightly) + keep } \\
\text { medium }\end{array}$ & $\begin{array}{l}\text { comedy play; modify } \\
\text { source + interpret }+ \\
\text { change medium }\end{array}$ & $\begin{array}{l}\text { comic book } \\
\text { (e-book); rewrite } \\
\text { source + interpret + } \\
\text { change medium }\end{array}$ & $\begin{array}{l}\text { same as GR; } \\
\text { modify source + } \\
\text { keep medium }\end{array}$ \\
\hline $\begin{array}{l}\text { Mode of } \\
\text { engagement }\end{array}$ & $\begin{array}{l}\text { telling: verbal } \\
\text { (including } \\
\text { paratexts) }\end{array}$ & $\begin{array}{l}\text { (one-off) showing: } \\
\text { acoustic, verbal, } \\
\text { visual (possibly } \\
\text { tactile and nasal) }\end{array}$ & $\begin{array}{l}\text { showing + telling: } \\
\text { visual, verbal (added } \\
\text { paratexts; scrolling } \\
\text { down to read) }\end{array}$ & $\begin{array}{l}\text { same as GR but } \\
\text { with modified } \\
\text { paratexts }\end{array}$ \\
\hline
\end{tabular}




\begin{tabular}{|l|l|l|l|l|}
\hline Sender & $\begin{array}{l}\text { ancient playwright } \\
\text { + translator } \\
\text { (copyright holder } \\
\text { of GR) }\end{array}$ & $\begin{array}{l}\text { director (modern; } \\
\text { copyright of } \\
\text { performance; other } \\
\text { legal constraints) }\end{array}$ & $\begin{array}{l}\text { adapter/illustrator } \\
\text { (copyright holders of } \\
\text { GR and EN) }\end{array}$ & $\begin{array}{l}\text { same as GR + } \\
\text { translator }\end{array}$ \\
\hline Consumers & $\begin{array}{l}\text { restricted: } \\
\text { directors, } \\
\text { philologists }\end{array}$ & $\begin{array}{l}\text { broad: theatre and } \\
\text { drama festival goers }\end{array}$ & $\begin{array}{l}\text { broad: children and } \\
\text { adults }\end{array}$ & $\begin{array}{l}\text { relatively } \\
\text { restricted: children } \\
\text { and adults }\end{array}$ \\
\hline $\begin{array}{l}\text { Institution and } \\
\text { Market }\end{array}$ & $\begin{array}{l}\text { bookshops } \\
\text { (education, } \\
\text { creative practice) }\end{array}$ & $\begin{array}{l}\text { theatre company } \\
\text { (profit, } \\
\text { entertainment); }\end{array}$ & $\begin{array}{l}\text { online bookshops } \\
\text { (education, } \\
\text { entertainment, } \\
\text { profit) }\end{array}$ & $\begin{array}{l}\text { online bookshops } \\
\text { (visibility, } \\
\text { entertainment, } \\
\text { profit) }\end{array}$ \\
\hline
\end{tabular}

Understanding adaptation may require more than the examination of the process of production, that is, the interpretation and substantial rewriting of Aristophanes in a new medium. Occupying specific niches in cultural transmission, adaptations are excellent indicators of creative engagement in a given moment. Aristophanic comic books, for instance, first appeared at the exact moment that the popularisation of Aristophanes in performance and education was complete and when Modern Greek usage became the norm. Throughout their afterlife, the comic books (and, recently, an animated version in DVD) maintained a clear educational function. On the other hand, the comic book translation swerves away (slightly) from this function. For example, footnotes and educational explanations are omitted, whereas comic elements are foregrounded. Further contextual framing of metabase may lead to copyright issues and market motives. After all, it is not self-explanatory that a comic book should be translated out of a minor language into more dominant languages and for cultural spaces where Aristophanes may not be part of the school curriculum or not shown on stage with the same frequency. Interviews with creators, translators and publishers can help elucidate these points, but were beyond the scope of this paper. An additional interesting avenue for future research is the impact of formats on reception, especially because using electronic devices to consume cultural goods is becoming the norm. ${ }^{6}$ Scrolling down in an e-book is certainly a less traditional way of reading than the usual non-linear mode of reading comics. These are implications that can be taken on board in the study of other comic adaptations in different locales/languages, especially because multimodal literacies and the power of image in creative expression and business interactions will only continue to evolve in the future, shaping the way we see our identity and position vis-à-vis other cultures.

\section{NOTES}

1. I would like to thank Mr. Apostolides and Mr. Akokalides, copyright holders of the comic books and their translations, for kindly granting me permission to reproduce panels in this article.

2. In the translation, Scythians are portrayed with a mixture of baby talk, ungrammaticality (absence of plural and third person verb affixation, absence of the copula verb) and (African American) slang ('bros,' 'man,' 'sweet mama').

3. I have also consulted the 1993 and 2007 Modern Greek translation of Assemblywomen and Thesmoforiazusae respectively because they both feature the original in Ancient Greek and are not bowdlerized (unlike Stavrou's 1967 translation).

4. 'Praxagorism' more readily alludes to a personal movement and does not function as a paronym to Marxism as it does in the original.

5. This narrative surprise is sustained further down when the Thesmoforia meeting is framed as a radical feminist event: speakers address each other as 'comrades' and generally discuss 'phallocracy' or specifically dismiss Euripides' 'misogyny' (LD/pp.19-21). 
6. According to a recent Greek Statistics Agency, 6/10 Greeks have access to Internet through PCs, tablets or mobile phones and 3/10 order goods online $<$ www.statistics/gr $>$ (visited on 16 September 2016).

\section{REFERENCES}

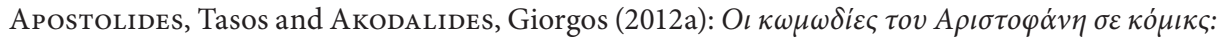

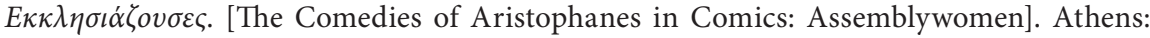
Metaichmio.

Apostolide, Tasos and Akodalides, Giorgos (2012b): The Comedies of Aristophanes in Comics: Assembly of Women. (Translated by N. Spiropoulou). Athens: Metaichmio.

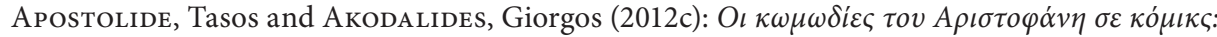
$\Theta \varepsilon \sigma \mu о \varphi о \rho ı \dot{\alpha} \zeta o v \sigma \varepsilon \varsigma$. [The Comedies of Aristophanes in Comics: Women of Thesmoforia]. Athens: Metaichmio.

Apostolide, Tasos and Akodalides, Giorgos (2012d): The Comedies of Aristophanes in Comics: Ladies' Day. (Translated by N. Spiropoulou). Athens: Metaichmio.

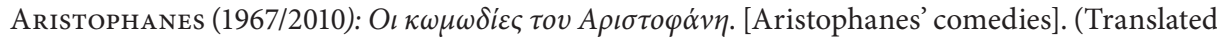
by Thrasyvoulos Stavrou). $11^{\text {th }}$ Edition. Athens: Estia.

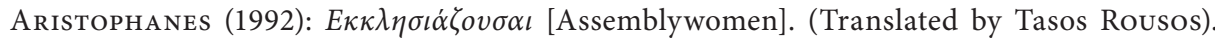
Athens: Kaktos.

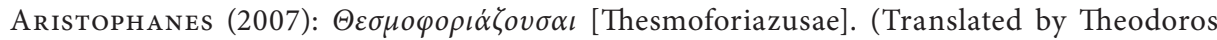
Mauropopoulos). Athens: Zetros.

Attardo, Salvatore (2002): Translation and Humour An Approach Based on the General Theory of Verbal Humour (GTVH). The Translator. 8(2):173-194.

Bergman, Kerstin (2014): From Literary Girl to Graphic Novel Hero - Transmedial transformation of Stieg Larsson's Lisbeth Salander. In: Karen SeAGo, Jonathan Evans and Begoña Rodriguez eds. Crime Translation. Special Issue JoSTrans. Vol. 22:93-109.

Chan, Leo (2012): A Survey of the 'New' Discipline of Adaptation Studies: Between Translation and Interculturalism. Perspectives: Studies in Translatology. 20(4):411-418.

Dudley, Andrew (2012): Adaptation. In: Timothy Corrigan, ed. Film and Literature. An Introduction and Reader. $2^{\text {nd }}$ edition. London/New York: Routledge, 65-73.

Ewans, Michael (2010): Translating Aristophanes into English. In: Delia Chiaro, ed. Translation, Humour and Literature. London: Continuum, 77-90.

Foley, Helene (2014): Performing Gender in Greek Old and New Comedy. In: Martin Reverman, ed. The Cambridge Companion to Greek Comedy. Cambridge: Cambridge University Press, 259-274.

Groensteen, Thierry (2007): The System of Comics. (Translated by Bart Beaty and Nick NGUYeN). Jackson: University of Mississippi Press.

Jenkins, Herny (2012): Introduction. Should we Discipline the Reading of Comics? In: Matthew Smith and Duncan Randy, eds. Critical Approaches to Comics. Theories and Methods. London/New York: Routledge, 1-14.

Hayley, Emma (2010): Manga Shakespeare. In: Toni Johnson-Woods, ed. Manga: An Anthology of Global and Cultural Perspectives. London: Continuum, 267-280.

Hutcheon, Linda (2013): A Theory of Adaptation. $2^{\text {nd }}$ Edition. London/New York: Routledge.

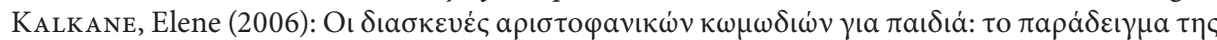


Example of Peace by A. Zarabouka]. Keimena. Vol. 4: 1-21.

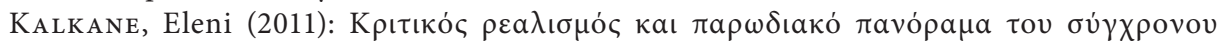

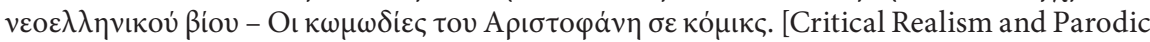
Panorama of Modern Greek life - Aristophanes' Comedies in Comics]. In: Despoina

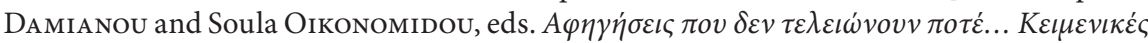

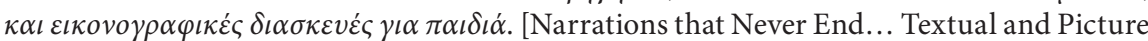
Adaptations for Children]. Athens: Papadopoulos Publications, 110-130. 
LefÈvre, Pascal (2000): Narration in Comics. Image and Narrative. Issue. 1. Visited on 16 September 2016, <http://www.imageandnarrative.be/inarchive/narratology/pascallefevre.htm>.

Lefèvre, Pascal (2011): Some Medium-Specific Qualities of Graphic Sequences. SubStance. 40(1):14-33.

Lefèvre, Pascal (2012): Mise en Scène and Framing. Visual Storytelling in Lone Wolf and Cub. In: Matthew Smith and Duncan Randy, eds. Critical Approaches to Comics. Theories and Methods. London/New York: Routledge, 71-83.

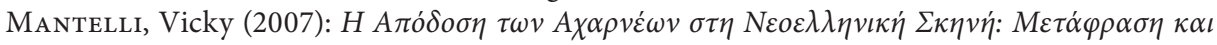
$\Pi \alpha \rho \alpha \dot{\sigma \tau} \alpha \sigma \eta$. [The Adaptation of Acharnians for the Modern Greek Stage: Translation and Staging]. PhD Thesis, Unpublished. Athens: University of Athens.

Mantelli, Vicky (2013): Translating Aristophanes' Humour for the Greek Modern Stage: The Acharnians at the National Theatre of Greece (1965-2005) and the State Theatre of Northern Greece (1991-2010). European Journal of Humour Research. 1(1):67-83.

Milton, John (2009): Between the Cat and the Devil: Adaptation Studies and Translation Studies. Journal of Adaptation in Film Performance. 2(1):47-64.

Molotiu, Andrei (2012): Abstract Form: Sequential Dynamism and Iconostasis in Abstract Comics and Steve Ditko's Amazing Spider-Man. In: Matthew Smith and Duncan RANDy, eds. Critical Approaches to Comics. Theories and Methods. London/New York: Routledge, 84-100.

Perret, Marion (2004): Not Just Condensation: How Comic Books Interpret Shakespeare. College Literature. 31(4):72-93.

Revermann, Martin (2006): Comic Business: Theatricality, Dramatic Technique, and Performance Contexts of Aristophanic Comedy. Oxford: Oxford University Press.

Robson, James (2006): Humour, Obscenity and Aristophanes. Tübingen: Gunter Narr Verlag.

Robson, James (2011): Lost in Translation? The Problem of (Aristophanic) Humour. In: Lorna Hardwick and Christopher Stray, eds. A Companion to Classical Receptions. Oxford: Wiley-Blackwell, 168-182.

Robson, James (2013): Aristophanes: An Introduction. London: Bloomsbury.

Singer, Marc (2012): Time and Narrative: Unity and Discontinuity in The Invisibles. In: Matthew Smith and Duncan Randy, eds. Critical Approaches to Comics. Theories and Methods. London/New York: Routledge, 55-70.

Sabeti, Shari (2014): The 'Strange Alteration' of Hamlet: Comic Books, Adaptation and Constructions of Adolescent Literacy. Changing English. 21(2):182-197.

StAM, Robert (2012): Beyond Fidelity. The Dialogics of Adaptation. In: Timothy Corrigan, ed. Film and Literature. An Introduction and Reader. $2^{\text {nd }}$ Edition. London/New York: Routledge, 74-88.

Vandaele, Jeroen (2010): Narrative Humor (1): Enter Perspective. Poetics Today. 31(4):721- 785.

Van Steen, Gonda (2000): Venom in Verse: Aristophanes in Modern Greece. Princeton: Princeton University Press.

Van Steen, Gonda (2002): Trying (on) Gender: Modern Greek Productions of Aristophanes' Thesmoforiazusae. American Journal of Philology. 123(3):407-427.

Venuti, Lawrence (2007): Adaptation, Translation, Critique. Journal of Visual Culture. 6(1):2543.

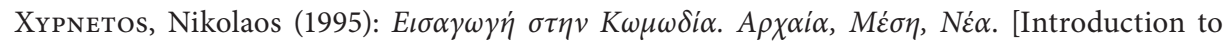
Comedy: Old, Middle and New]. Athens: Gutenberg.

Zanettin, Federico (2008): Comics in Translation: An Overview. In: Federico Zanettin, ed. Comics in Translation. Manchester \& Kinderhook NY: St Jerome Publishing, 1-32.

Zanettin, Federico (2010): Humour in Translated Cartoons and Comics. In: Delia Chiaro, ed. Translation Humour and the Media. London: Continuum, 34-52. 